\title{
Editorial
}

\section{Partnership in health: beyond the rhetoric}

Over the years the trumpet has sounded for joint working, inter-agency working, and multi-sectoral working; for collaboration and alliances; and most recently for "partnerships"- between private and public sectors, professionals and lay people (whether "patients" or "the public"). Although the words may have changed over the past 20 years, the rhetoric remains the same: whether in health services, social policy or urban renewal, working together is a good thing. It will produce more efficient, effective and appropriate responses to individual and population need-or so we are told.

In recent months a number of UK policy initiatives have pushed the notion of partnership to the very centre of the policy arena. The green paper, $A$ healthier nation, ${ }^{1}$ proposes a "contract" for partnerships between national government, local communities, and individuals to improve health. The Social Exclusion Unit, set up last summer in the cabinet office, attempts to move beyond separate departments of government to tackle the multiple causes of impoverishment, disempowerment, and exclusion in society. The white paper, The new NHS-modern and dependable, ${ }^{2}$ goes so far as to suggest a new statutory duty to be imposed on health organisations mandating them to work "in partnership". Moreover, as western governments seek to tackle the enduring health and social problems of the late 20th century the clarion-call for partnership can be heard echoing through the European Union and beyond.

The idea that working together is better than working apart has underpinned all the great social movements of our time. Indeed, it would be difficult to imagine a movement that did not draw in or work across a wide range of different social groups. The way in which working together is understood and enacted has of course varied according to the historical moment, but the process always entails the mobilisation and deployment of power to change some aspect of society. The 19th century public health movement is a good example of the development of partnerships between unlikely allies, and it also illustrates the way in which power operates dialectically: change brings resistance, and both sides become adept at forming alliances. In the 1840 s Chadwick found an unlikely patchwork of interests combining in resistance to the setting up of the Board of Health: "we prefer to take our chances with cholera than to be bullied into health," proclaimed the Times. ${ }^{3}$ In the 1990 s, the case for a complete ban on smoking in public places is meeting the powerful resistance of a tobacco lobby containing a range of interests appearing in different shapes and forms. And as many community groups know only too well, arguments for better regulation of road traffic can be drowned out by a very powerful and well rehearsed chorus of voices.

The realities of power and influence mean that public health movements need to work together in partnership if they are to stand any chance of effecting change. What is commonly referred to as "the new public health movement", spurred on by WHO's Health for All initiative in the 1970s and encompassing the important Healthy Cities Movement, has been premised on the notion that success depends on inter-sectoral working to a shared agenda. ${ }^{4}$ But there is an increasingly prominent cynical view that working together to achieve common objectives is an ideal that all may aspire to but few achieve. In this context, it is important to ask whether we have learnt anything over the decades about the requirements for positive and successful working across boundaries. What do we need to put in place to make reality of the partnership rhetoric?

Research has highlighted a number of important aspects of "successful partnership". Most partnerships-whether between organisations or individuals, or both-involve differentials in power and status and different cultures, value positions and priorities. For partnerships to work these differences need to be made explicit and settlements "negotiated". Most importantly, there needs to be a clear understanding of the objectives that (potential) partners share - the "common ground". Mutual trust and respect are important but they do not just come, they need to be built. This means recognising that people are of "equal worth" in bringing different perspectives to bear on an issue, ${ }^{56}$ and then understanding that those perspectives represent expertise or knowledge of "equal weight" to the partnership.

Contemporary partnerships for health are complex, and one of their key characteristics is the centrality of public involvement. However, public participation is perhaps the most challenging aspect of "health partnerships". Power differentials are at their greatest between professionals and lay people, and between formal organisations and community groups. Lay knowledge - the knowledge we all gain through the experience of living in this or that place or having experience of particular health problems - is the least valued source of knowledge in modern societies permeated as they are with an all to often unquestioning acceptance of the might of science. Moreover, there is of course no unitary "public opinion" but rather a multitude of voices waiting to be heard. And each voice may express multiple identities - they (we) can be patient and service provider, lay and professional, at the same time. Each of us is a member of many different publics and speak from different perspectives at different times. Developing sustainable ways of involving the diversity of publics are difficult. The Healthy Cities Movement has made more progress than most partnerships to engage publics in priority setting, decision making and action for health, but there is still a long way to go. ${ }^{7}$ If, as Aneurin Bevan argued, "the debunking of the expert is an important stage in the history of democratic communities," ${ }^{8}$ then equality is necessary if partnership is to be anything more than a handy tool in a manager's toolbox.

There is no simple answer to all of this but one thing seems certain: we cannot have partnerships for health that do not tackle the multiple problems of living in modern societies. The basic premise is that modern societies, and particularly urban areas and their public health and health care systems, are complex and adaptive systems and, as such, have a number of characteristics. Prominent among these are that there are multiple perspectives on the system, no one of which is complete. No one agency can "fix things"- whether they are broken or not! Parts of the system are interdependent, so that action by one agency will have unintended consequences for other parts and for the system as a whole, and a whole system cannot be understood from looking at the parts. An understanding of the complexity of modern organisations and the systems of 
which they are a part has lead to important innovations in the management of organisational development and change variously referred to as large group interventions or whole systems approaches. ${ }^{9}$

New more holistic ways of approaching development and the management of change in complex systems are evolving. For example, a whole systems approach has been central to the English Urban Health Partnershipsmultisectoral initiatives established since 1994 and aimed at improving services for older people in 11 local sites in London, Newcastle, and Liverpool. These have arisen out of the work of the London Health Partnership involving the London based King's Fund, the NHS, and a number of charities. ${ }^{10} \mathrm{~A}$ whole systems approach to change management in the public health field has also been tried in several North American cities, including, for example, the Milwaukee Common Ground Project to reduce infant mortality. ${ }^{11-13}$ This approach offers a framework and practical methods for developing longer term sustainable partnerships that involve "the publics", with some evidence of success. ${ }^{14}$ There is a particular focus on the importance of building relationships and on developing communication, information, and meanings. There is also an assumption that the knowledge needed to make change happen is in the system, but there has to be greater openness to the equal worth of the people involved and the equal weight to be given to their views.

Partnerships are relationships, and relationships are inevitably about power and control, but they are also to do with dialogue, negotiation, and the development of shared objectives. As EP Thompson has noted in the context of a discussion of social class: "the relationship must always be embodied in real people and in a real context." ${ }^{15}$ To make partnerships work we have to have a better understanding of what motivates "real people" and about the context they are operating in. In the public sphere-as in the domestic sphere-we still have much to learn about these issues, but the current public health agenda does give new impetus to the search for a better understanding.

JENNIE POPAY GARETH WILLIAMS

Public Health Research and Resources Centre, University of Salford 4th Floor, Humphrey Booth House, Hulme Place, Salford M5 4QA

Correspondence to:

Professor J Popay.

1 Secretary of State for Health. Our healthier nations: a contract for health. Cmm 3852. London: HMSO, 1998

2 Secretary of State for Health. The new NHS: modern-dependable. Cmm 3807. London: HMSO, 1997.

3 Porter R. The greatest benefit to mankind: a medical history of humanity from antiquity to the present. London: Harper Collins, 1997:412.

4 Ashton J, ed. Healthy cities. Milton Keynes: Open University Press, 1992

5 Stacey M. The power of lay knowledge: a personal view. In: Popay J, Williams G, eds. Researching the people's health. London: Routledge, 1994:85-98.

6 Williams G, Popay J. Researching the people's health; dilemmas and opportunities for social scientists. In: Popay J, Williams G, eds. Researching the people's health. London: Routledge, 1994:99-114.

7 Coote A, Hunter DJ. New agenda for health. London: Institute for Public Policy Research, 1996.

8 Smith D. Aneurin Bevan and the world of South Wales. Cardiff: University of Wales Press, 1993.

9 Bunker B, Alban B, eds. Large group interventions. Fournal of Applied Behavioural Science 1992 (special issue);28:4.

10 Gordon P, Pampling D, Pratt M, Fischer M, Ombler-Spain S, Evans K. Primary health care in cities - a whole systems approach. London: London Health Partnership, King's Fund, 1996.

11 Aronson A. Unlikely partnerships in a medicaid managed care environment: the Milwankee Common Group Project to reduce infant mortality. In: Proceedings of the American Public Health Association Annual Meeting, October 30th, San Diego, California. Milwaukee: State Maternal and Child Health Service, 1995.

12 RiverValley Partners Inc. First annual report. Chattanooga, TN: River Valley Partners, 1994.

13 Weisbord M, Janoff S. Future search: an action guide to finding common ground in organisation and communities. NY: Berrett-Koehler, NY: 1995.

14 Gordon P, Pampling D, Pratt M, Fischer M, Ombler-Spain S, Evans K. Releasing resources. London: King's Fund, 1998.

15 Thompson EP. The making of the English working class. Middlesex: Harmondsworth, Penguin, 1968:9. 